\title{
The Syrian Conflict: A reading on the Regional Dimensions and Implications
}

Received: 24/11/2019; Accepted: 17/03/2020

\section{Abstract}

The aim of this study is to shed a light on the impact of the Syrian conflict, as a complex case than in the Arab world, and as an important strategic event in the context of the Arab spring on the regional States in the Middle East, due to the importance of the Syrian geopolitical position Furthermore, its impact on shaping the future of the region, and on shaping the relations between their countries and their peoples. Despite the global nature of the Syrian effects, the Middle East's Countries are the most affected by geopolitical developments and overlapping of relations and interests in the region, which makes these countries, follow the events in terms of impact on its internal situation and relations with neighboring countries

Keywords: the Syrian conflict; The middle east; Iran; Turkey, the Gulf States.
Hocine Laarid *

\section{Riad Hamdouche}

Faculty of political sciences and International relations, University of Constantine 3, Constantine, Algeria

\section{Résumé}

Cette étude vise à faire la lumière sur le conflit syrien et son impact sur les voisins régionaux arabes et les puissances non arabes, et divers régionaux, ce qui a contribué directement à modifier le chemin de conflit interne syrien entre soutenir l'opposition syrienne et le régime prosyrien, et le résultat de ce cercle toujours plus large de groupes extrémiste et séparatiste à la lumière des tendances sectaires croissantes qui sont devenues comprises comme un facteur déterminant dans lequel la nature des conflits que vous connaissez le Moyen-Orient. Ainsi que le conflit syrien est un facteur probable dans l'équilibre de la région, et aura des effets décisifs dans la détermination de son avenir et les voies par l'avenir.

Mots clés: le conflit syrien; Iran, Turquie; Moyen-Orient; Etats de Golfe.

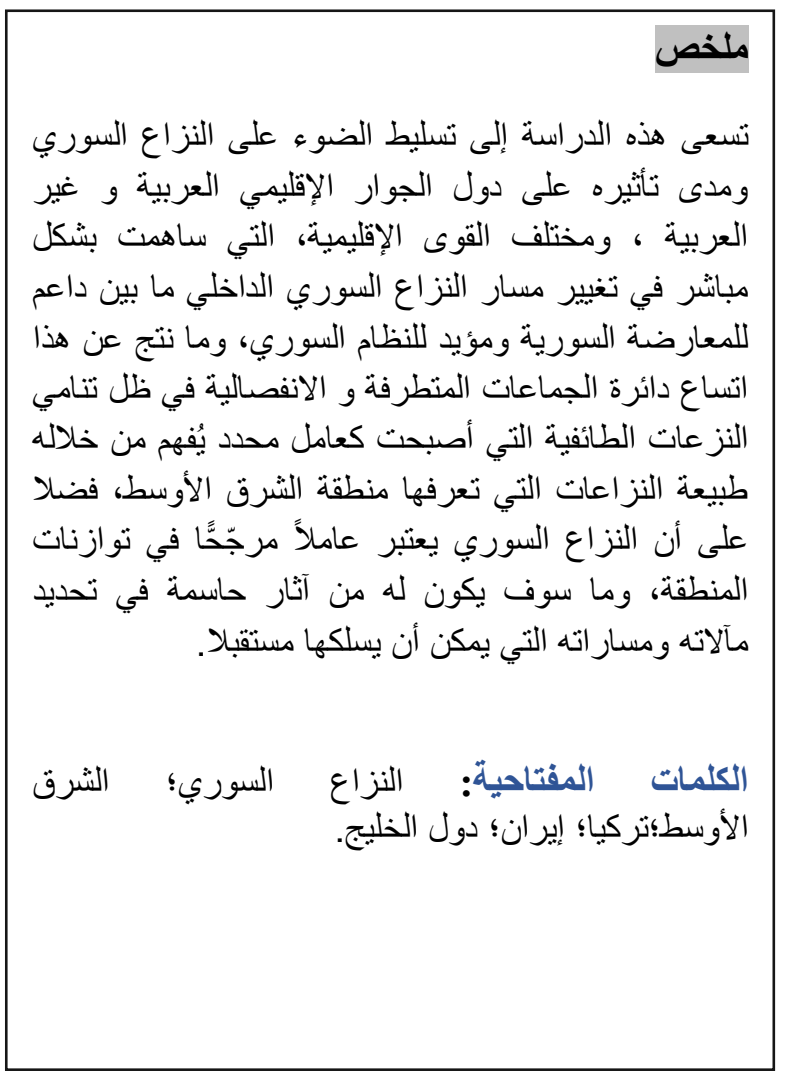

* Corresponding author, e-mail: sun5set.hocine@hotmail.fr 


\section{1-Introduction :}

Beginning in Deraa and Damascus in March 2011 and quickly spreading to other cities, Syrians such other Arab countries calling for political and social reforms as part of what was labelled "Arab Spring" in the Middle East and North Africa, which repeatedly confronted with violent response tear gas, sniper fire, and mass arrest.

A few months later, which have been one of a constant regime escalation towards the protests, more than 100 protesters were killed by security forces bullets.

The facts in Syria knew more escalations, incidents of armed insurrection and defected officers which made later an armed opposition against Bashar Assad regime. As a result of that, the Syrian conflict becomes a bloody complicated issue in the Middle East, hundreds of thousands were killed including children, famine, homelessness and millions of refugees in neighboring countries and even towards Europe (5.6 million), creating a critical humanitarian crisis and the economy of the country was in shambles. In addition, giving an opportunity to other regional and international States to intervene directly in the armed conflict which is entered its ninth year. Therefore, those regional States like Iran, Turkey, Israel and the Gulf States, and some armed militias such as Hezbollah and The Kurdistan Workers Party, making the matter worse than before.

Syria has become the epicenter of regional conflicts and competition in the Middle East.

The regional balance of power, ideological clashes, have melted down, and what began as a peaceful uprising for democracy and dignity, has rapidly transformed into an ethno-sectarian conflict, that is progressively more difficult to contain within the boundaries of the Syrian State. So the Syria future is at stake due to the raising of sectarian violence, which spills across the Country's borders, as well as the strategic interests of Turkey, Iran, Saudi-Arabia, and Israel will face a direct, immediate and crucial challenges.

Thus, we ask the following question: to what extent does the Syrian conflict affect the Arab and Non-Arab neighbours in the Middle

\section{East?}

\section{2-Turkey the ill-at-ease in Syria's conflict (hedge strategy)}

As a country which combines an Islamic identity with democracy, Market economy and a strong alliance with the western countries (USA). In addition to the soft power which the country has, Turkey had a strong and efficient military. It was initially a leading flame for the moderate Islamist opposition during the Arab Uprisings (Arab Spring) calling for multiple reforms and for giving the chance for people to decide its destiny. In fact, turkey has actively engaged in regime change by supplying arms and fighters to opposition groups. "Weapons had begun trickling into Syria as early as 2011, through backdoor channels organized by Islamist networks, smugglers, merchants, and Bedouin clans, but also with increasingly overt support from Turkey, Qatar, and Saudi Arabia”. (Lund, 2017).

Obviously, the Turkish policy towards The Syrian conflict had been clear until recently, its aim was to replace The Syrian regime with new other one and stand with the opposition side. It was a regional actor during the first phase of uprising, where it played the incubator and the sponsor role by giving support the Syrian Diaspora organizations such the Syrian national council, and the Syrian exiled brotherhood. The Turkish action has not just been initiated through proxies. It froze Assad's regime assets in Turkey, prohibited military sales to Damascus, and suspended Syrian ties with the Turkish central bank. ( Oktave Ozden Zeyneb, 2015: p06).

There are some several factors that limited the Turkish enthusiasm to intervene in Syria:

1- Turkey avoids any confrontation with Russia, which had become more directly and actively engaged on the side of Bashar Al Assad's regime, and intervened on a grand scale in Syria. 
2- Turkey needed Russia's cooperation in order to prevent any creation of PKK linked Kurds entity in Northern Syria. It perceived a serious threat from the People's Protection Unites which is the Syrian-Kurdish militia that dominates the Syrian Democratic Forces. Not to mention that The People's Protection Unites is considered as the Syrian wing of the Kurdistan Workers Party (PKK), the designated group which has been waging an insurgency against Turkey for more than 30 years. It sought to create a "safe zone" stretching some 20 miles deep into the Syrian democratic forces held northeastern Syria, from which it would drive out the People's Protection Unites.( Tahiroglu and Gabel: 2019). That's why, Turkey was more cautious in its approach to Syria.

3- Turkey recognized that any uncalculated intervening in Syria may put it in an enviable position with Iran, the latter which had good and advantageous relations with turkey. Also, it's considered the main buyer of Turkish manufactured goods. Furthermore, Iran is Turkey's second most important supplier of natural gas and delivery of more than $40 \%$ of its oil, which was also potentially jeopardizing by supporting the opposite side that is against Iran within Syria.

4- There is a significant opposition inside Turkey's policy towards Syria, and this opposition is further strengthened by the increasing number of terror attacks conducted by some Syrian organizations inside Turkey.

5- The Turkish ability to play a major role in Syria became increasingly difficult, because of the de facto collapse of the Syrian national council and the decisive role that the Syrian Muslim brotherhood played as a main alternative of Turkey inside Syria. On the other hand, because of the increased dominance of some extremist organizations on the battle field in Syria, as well as the Assad's partial success in reconquering parts of Syria.( Altunisik: 2016:p39).

Although, the Turkish existential interest in preventing any separatist Kurdish entity on its southern border, it is not directly enmeshed in the two conflict structure of the region: the Arab-Israeli conflict and the Iran-Saudi Arabia cold war. Regardless, Turkey as being part of the Middle East and at the same time as being a sort of buffer State between Europe and the Middle East, (Akturk, 2017: p88), and playing an important role in preventing refugees to reach Europe, that gives it a flexibility in dealing with all other external in the Syrian conflict and may enable it to pursue its interests successfully, in particular regarding the Kurdish question. To varying degrees, Turkey has been following a hedging strategy towards the Middle East and its regional actors, that means it aim for the best and prepare for the worst as Quick said.

Thus, it is clear that the hedge strategy contributes to the security of States as individual units, even if it may be weaken the effectiveness of the alliance indirectly due to its ambiguous nature. (Guzansky, a2015:p40)

\section{3- Syria: the fateful question of Iran}

Since the Iranian revolution in 1979, Iran has been closely linked with Assad's Family regime, and has provided diplomatic, economic, and political support to Syria at many crucial times.

Iran and Syria have strong ties for more than three decades, thus, Iran's decisionmakers understand that the collapse of the Syrian Regime the important and the strategic ally in the Middle East is a major loss for Iran's strategic interests in the region. Also, it will lose its strategic unique position left by the exit of Iraq from the regional equation, and the objection's axis will receive a blow to the core if it drove Syria out of the balancing process and probably, it will be the strongest strike for Iran since the Iran-Iraq war. As well as Iran's vision of the Syrian conflict depends on that Syria is the soft link between Iran's resistance shoulder and its persistent Hezbollah-led fist. The purpose behind trying to demonstrate and strike Syria is to separate the shoulder of resistance from its grip. Therefore, Iran recognizes that breaking its strategic ally Syria will weaken and restrictive its ability to act against its interests in the region. 
Iran sees that any external interference or the collapse of the Syrian regime will change the game's rules in the region, and would make the possibility of threatening Iran's nuclear program more likely and realistic.

According to these facts, Iran's believes that it has a vital interest in indulging in it, defeating opponents of Bashar's regime and even providing unconditional support to the regime. This is the consensus of the ruling elite in Iran, which cannot be changed by changing the decision makers.

Therefore, Iran intervened directly and strongly to prevent the fall of the regime in Syria, rushed to provide all the assistance and support on multiple levels to Bashar Al Assad, and stands with him with all its power, has also made huge financial investments in Syria in different projects(( Goodrazi), it offers billions of dollars in order to prevent the Syrian economic collapse, and supply him with weapons through Iraq, planes passing over Turkey, some of them were seen, and ships crossing the Suez Canal loaded with weapons and modern equipment. Therefore, it is possible to say that Iran has dealt with the Syrian conflict according to its national interests and according to its regional alliances without forgetting its status in the region.

Through the above-mentioned, the regional balance of power plays a crucial role alongside to aforesaid factors and reasons before this senior strategic, geopolitical, geo-economic and security alliance among Syria and Iran. For Iran's viewpoint, if the Alawite regime in Syria led by Bashar Assad the spoiled son of Iran is overthrown, the regional balance of power will tip against Iran and will be in favor of other Sunni majority States such as the Arab Gulf States: Saudi-Arabia, Kuwait, Emirates and Qatar.

\section{3-The Gulf States and the Middle East's Balance of Power}

Iran has been always a big concern for the Gulf States societies; they pay great attention to Iranian influence in the region after the Iranian Revolution in 1979. (Wehrey, 2014: p44).That's why; the interests and policies of the Arab Gulf States towards the Syrian conflict are often restricted to their desire to keep Syria out of Iranian Orbit. This policy is mainly driven by the Gulf States long term interest in countering Iran's power and its influence in the Middle East( Guzansky, b:2015:p39).On the other hand, The Arab Gulf States fear of establishing a Persian miniempire in the Middle East by Iran if it successfully takes control in the course events in Syria or even key areas of that country.

This is mostly imagined as an arch of Iranian-led Shia dominance, stretching from Afghanistan through Iran, Iraq, Syria, and into southern Lebanon.

Also, there is a fear of potential zone of Iranian hegemony in Shia population centers in the Gulf region itself.( Ma'oz, 2007: p07)Or the Iranian control of strategic maritime areas that would surround and secure control of the Gulf waters and access to them.( Walker,2006) As well, the Arab Gulf States see that even some Iranian officials within The Islamic Revolutionary Guard Corps, are leading a secret strategy for the long-term domination of these key areas of the Middle East.( Ulrichsen, 2009)

Partly, both Qatar and Saudi-Arabia become regional actors after the retreat of Egypt's role in the region over the past twenty years, in addition to the enormous economic resources that they have. Although, Qatar and Saudi-Arabia have sharply differed over armed groups, they have become the main financial and military backers of the Syrian opposition. Even some Muslim world organizations have aligned themselves against Syria's regime, including the Arab League which in March 2013 awarded Syria's seat to the National Coalition for Syrian revolutionary and opposition's forces. All this was under the direct pressure from both Saudi-Arabia and Qatar(Hydemann, 2013). Somehow that has been given sectarian character to the roles of these institutions.

It is possible to say that the real significance of this settlement is the way in which the Gulf States have dealt with the Syrian conflict. Basically, they have given it a sectarian character, in addition to linking it to the regional balance of power between SaudiArabia and Iran. As a part of what was called a proxy war and a new Middle East's cold war. 


\section{4-Israel: The observed foe:}

It is obvious for any follower of Israeli-Syrian relations that hostility is what distinguishes these relations. There are some important points that can explain these tensions and bad relations, comes first the Palestinian Issue within what is known "The Arab-Israeli Conflict", likewise Israel conquered the Golan Heights, an area about 1200 square kilometers, in June 1967 and annexed it in December 1981.

The friendly relations among Syria, Iran, and Hezbollah, which made an evil axis according to Israel, As well, the supporting of Iran and Syria to Hezbollah by weapons via the Syrian-Israeli borders, despite the list of confrontations, the border between Israel and Syria has remained calm, even in the absence of an official peace, up until the Syrian conflict.

Since the beginning of the Syrian uprising in 2011, the Israeli policy towards Syria has been characterized by waiting and sees policy, awaiting the outcome of the conflict, due to the complex motives that drive Israel in its position on the ongoing conflict. In addition, there are several principal objectives Israel has towards the Syrian conflict:

1- Minimizing the Iranian's influence in Syria, so the Syria's regime collapse will be a direct blow to Iran and the radical axis (Iran, Hezbollah and Syria) led by Iran.

2- Preventing the transfer of dangerous and advanced weapons to Hezbollah. Where Syria is considered the main channel which weapons pass through to Hezbollah which means the internal conflict results will have direct influence on Hezbollah power, policies, and even on political and security events in Lebanon in general.

3- Undermining the legitimacy of Syria's claims to the heights of Golan.

4- Preventing any credible military threat from Syria and Iran.

On the other hand, there are some points that make Israel want to support the Syrian regime survival:

1- The fear of a new Islamic radical regime in post-Bashar's regime era. Due to the existence of many radical armed groups which are fighting against the Syrian regime. Those probably menace the Israel State.

2- The effectiveness of Bashar Assad's regime for Israel, where Bashar and his father before played a pivotal role in maintaining the border security for 40 years, despite the absence of any peace agreement between the two countries.

\section{5-The Syrian conflict and the Kurdish question}

The history of the Kurdish question in the Middle East is a long and complex one. Separative among the States of Iran, Turkey, Iraq and Syria, the Kurds of Syria are ethnically akin to the Kurds in the countries which are mentioned previously, they are one of the largest nations in the World without their own State. Where Syria's Kurds constitute nearly $10 \%$ of Syria's population and number around 2 million people. They have suffered from systematic campaigns of ethnic cleansing and policies of Arabization(Catar, 2015), since the formation of the modern Syrian State in 1920.

The uprising in Syria in 2011 put the Kurds between the hammer and anvil; however, both options are risky, they had to choose between joining opposition groups and allying themselves with the Assad regime. On the one hand, turkey the stubborn enemy of the Kurds (which does not want to see them playing any major role in the post-Assad era) is affiliated with the Free Syrian Army. On the other hand, the memories of Assad's crackdown on the Kurdish uprising in 2004 were still very much alive.( Schmidinger,2018:p79), Also, it has created some conditions and fertile ground for a major shift in Kurdish politics and society. The Kurdistan Democratic Party of Syria was the first Kurdish party which founded in 1957, and most other political Kurdish parties derived from it(Allsopp,2015m p15), Those parties have struggled to mobilize and they have always been illegal however.

Due to the State suppression and the internal splits, fundamentally they have limited their activities to the cultural sphere.( Gunes and Lowe, 2015: 04). In the 1990s, the 
Syrian government gave the PKK support and haven, thus the number of the Kurds who joined the Party increased during this period. (Gunes, 2019:p61)

The Kurdish populated regions in Syria have been the significant political developments scene since the Syrian conflict broke out in 2011. The Kurds took control on the majority of Kurdish regions in Syria and created the conditions for the development of Kurdish political and military organizations, this was after the withdrawal of the Syrian forces in July 2012. On January in 2014, and precisely in the region of Rojava they created some Cantons as an administrative structure, and as a beginning for the establishment of their de facto autonomy. (Bengio, 2014: p04)

There are some factors have helped the rising of the Kurds Issue in world opinion:

- The Kurds forces in both Iraq and Syria were the first at the forefront against the rapid expansion of ISIS in 2014.

- The presence of ISIS in the region has played an incentive role for Kurdish nation-building and State -building.( Ibid : pp03-04)

- The Kurdish entity becomes a vital and independent player in the eyes of many in the international community.( Harris, 2018:105)

The direct support by international actors, such as, US, The United Kingdome, France, Spain, Australia, Canada and Germany, to the Kurdish Peshmerga forces (Osoegawa, 2013: p91) by weapons, ammunition and training.

- The US air force struck ISIS targets in the Kurdish areas in Syria which considered as a symbolic support showed by US and its allies to the direct defense of the Kurds.

In some ways, the post-2011 decomposition of Syria and Iraq, while it presented limited probably temporary openings, only highlighted the lack of a real regional backer for the Kurds. While the future is unpredictable, but it is possible that Kurds may be will maintain their autonomy in northern Syria, when the dust of the Syrian conflict settles, and this will cost them a heavy price however. Not to mention that they are surrounded by enemies, unfriendly States, and entities such as Turkey, Assad's regime, and the some extreme terrorist groups (ISIS before).(ibid).

\section{6-The impact of the Syrian conflict on Lebanon}

Since the last decades, the Lebanese government was forced to confront the reality of indirect rule under Syria when its civil war ended in 1990. To further its interests, Syria was directly intervened in Lebanon's political, economical, and social issues. (International Crisis Group, a2012: p01)In general, the Syrian policy towards Lebanon still defined by regional dynamics in the Middle East and its direct and strong relations with some mostly sectarian-based non-governmental actors more than official connections with Lebanese government itself. (International Crisis Group, b2014: p18)

Not surprisingly from the first days of Syrian uprising, that Lebanon would no long remain untouched, traditionally it has been under its neighbour's strong influence, as well as extremely close communal ties. Many were from the start that Damascus would seek to destabilize its neighbour across the border. Over decades, Lebanese communities were deeply affected by the Syria's regime bad behavior, and particularly, this the case of Sunnis in the north regions who feel solidarity with their Syrian brethren.(Christopher Philips, 2015:p359)

At first, Lebanon was hesitated and not ready to take a position towards Syrian uprising, merely it felt vulnerable, and even the central government's weakness on the domestic scene. That's why it was unable to take any step towards Syria. In fact, it is not surprisingly that Lebanon limited by sectarian elites and it is obvious that Hezbollah is the major Shiite's allay of the Syrian regime, which have given direct support to Bashar against the opposition, while the coalition of march 14 the Sunnidominated backs the opposition against the Syrian regime(ibid). Subsequently, the Lebanese split towards Syria formed sectarian proxy war. Two groups crossing the Syrian-Lebanese border: fighters and refugees, in this period the Lebanese social and political fabric was already jagged. The two countries share 365-kilometer, and historically, the Lebanese-Syrian border has been the most penetrating crossing point 
for weapons, people and groups as well as all kinds of cross-border smuggling. So the spillover effects of the Syrian conflict on Lebanon knew the most damaging on the country's sectarian relations, likewise, the anti-and pro-regime mobilization along largely Sunni-Shia fault lines led to a rise in conflict and instigation.(international crisis group, op cit).

In February 2012, especially in Homs, the situation in Syria worsened to the extent of the sectarian conflict, the Syrian regime targeted the opposition areas with a scorched earth policy and the sectarian massacres which had been committed by Shabiha, and this angered the Sunni groups in Lebanon, where they took part against the Syrian regime forces. (Joseph Bahout, 2014:p03) This was especially the case of Tripoli, Akkar, and the eastern Beqaa valley. (Geneive, 2017:p79). This made the Free Syrian army forces who battles in Homs or in Zabadani-a few miles away from Lebanese villages resort to these places, which seemed to them an imaginary frontier in order to get medical care, shelter, rest and resupply.(Reese, 2013:p10)

Anywhere, the indirect effects of internal, regional and international conflict on Syria more destructive than in Lebanon, in terms of raising sectarian tensions and violence, the refugees crisis, the spread of local and transnational Jihadists cells, or the relevant regional and international actors, the Syrian conflict has imposed new economic, social, political and security pressures on Lebanon.

\section{7-Iraq and the Syrian conflict: the mutual effect}

However, Iraqi-Syrian relations have been on a very bumpy road over the past decades, the Syrian conflict and the rising of sectarian nature of regional politics, has encouraged a new rapprochement between the two States. At first Iraq has been less prominently involved in the Syrian conflict. It hosts fewer Syrian refugees than any other neighboring country. Officially, it has shown that it is neutral, neither with the Syrian regime nor with the opposition. Under the official rhetoric of non-involvement, Iraqis have seen Syria almost entirely through the lens of their own ethno-sectarian conflicts.

When the arrival of Shiite Anwar al-Maliki to power in Iraq(Genieve, op cit, p22).Sunni Arabs have feared that they were being enslaved by the new regime as the Shiites were enslaved by the former regime. The crash of Iraq is believed to be reemerging in different ways inside Middle Eastern states, and in states ruled by Sunni leaders, the Shia are often seen as an enemy of the state (ideology) and threat to internal stability.

When the rising events in Syria became worst, the Iraqi Shiite government under Nouri al-Maliki has rushed to support the Syrian regime in its struggle with its Sunni dominated opposition. Also has welcomed the Iranian direct intervention in Syria, maintained its economic ties with the Assad regime, and permitted the moving of weapons and fighters into Syria by Iraqi's minority Sunni opposition. In addition there is evidence of growing cooperation among Kurdish communities across the Syrian border with northern Iraq.

Iraq has added additional weight to the Sectarianization and polarization of the conflict is the potential for spillover from Syria to reignite open sectarian conflict in Iraq. Furthermore, Iraq's concerns stemmed from a fear that the anti-Syrian regime groups (ISIS) elicit, if not empower, similar forces in Iraq. In fact, that what has really happened when ISIS militants from Syria captured large swaths of territory in the North and West of Iraq. Especially in Mosul, the second largest Iraq's city, in which thousands were killed and hundreds of thousands displaced. By the end of August 2014, the ISIS turned from an organization into a governing entity and declared the establishment of its Caliphate (Guidero and Hallward , 2019:p21). when it controlled an area bordering on Turkey and Jordan that spread from northeastern Aleppo, Syria to Jalawla, in eastern Iraq, a mere 38 Kilometers from the Iranian Border. 


\section{8-Conclusion}

The outcome of this conflict will have severe ramifications and implications across the Middle East and beyond. The condensation of the already emerging regional map, pitting a Shiite Iran-Iraq-Syria-Hezbollah axis against a Sunni Turkey-Gulf axis, would perhaps be the most significant geo-political regional effect of the Syrian conflict. It must be noted that initially the regional powers were aligned along the above mentioned lines. However, after nearly four years of conflict, three blocs have emerged in the region instead of two. The first consists of Saudi Arabia, the United Arab Emirates, Egypt and Jordan supporting the Free Syrian Army; the second consists of Iran, Syria, Iraq and Hezbollah backing the Assad Regime; the third consists of Turkey and Qatar assisting radical and jihadist groups such as ISIS and Jabhat al-Nusra with the aim of removing Assad from power.

The Syrian conflict revealed the reality of hidden conflicts and hatreds fueled by sectarianism, proxy wars, and then highlighting the zero equation in the sense of conflicts of existence which trying to eliminate the other. The majority of the countries that have been entered the Syrian conflict either directly or indirectly are Arab countries, which have been already divided whether among the opponents and the supporters of the Syrian regime. Therefore, it confirms the extent of the disintegration of the Arab regional Arab Order, due to the divergence of interests and the lack of a commune vision towards the security issues and conflicts defined by the Middle East's Region, which also makes the Syrian conflict as an attraction's point and fertile ground for extremists and jihadists groups, and their impact on the internal scope of other countries in the region.

Whichever path the Syrian conflict takes, the country's future is no longer in Syrian hands of alone. As a result of that; five broad trends in regional policy have emerged as of particular importance: the rise of Turkey as a regional power, the rise of Iran influence and the deepening of the strategic alliance between Syria, Iran, and Hezbollah. The continued shift of diplomatic weight in the Arab world towards the Gulf Sunni Islamist monarchies, such as Saudi-Arabia and Qatar, the rise of the Kurdish Issue, and the consolidation of ethno-sectarian politics in Iraq, furthermore the broader trend toward the sectarianism of regional balance of power politics in the Middle East.

The Syrian conflict has had a destructive effect on sectarian relations and has further radicalized divisions of Sunni and Shiite societies not just in the Arab world, but beyond it as well. Thanks to the increasingly intertwined conflicts in Iraq and Syria, jihadi groups are enjoying an unprecedented Golden Age. Like a boomerang, al-Qaeda and ISIS eventually will hurt all the countries that are currently supporting them. Turning a blind eye to the jihadists who join these terrorist groups, or even supporting them directly or indirectly, will exact a price. This alarms the fragmentation of the nation-state, the rise of separatist tendencies and the intensification of tensions on the borders. 


\section{Bibliography:}

1- Lund Aaron, "How Assad's Enemies Gave Up on the Syrian opposition", The Century Foundation, retrieved from: https://tcf.org/content/report/assadsenemies-gave-syrian-opposition/?agreed $=1$

2- Oktav Ozden Zeyneb, (2015), "The Syrian Civil War and Turkey-SyriaIran Relations", Syria Studies, , P06.

3- Tahiroglu Merve and Gabel Andrew, "Saving Northeastern Syria: How Washington Can Help Strike a Deal Between Turkey and the Kurds", Foreign Affairs, April $\quad 9^{\text {th }}$ 2019. $\quad$ From: https://www.foreignaffairs.com/articles/turkey/2019-04-09/savingnortheastern-syria

4- Altunisik Meliha Benli, (2016), "Turkey at a Crossroads: The Inflexibility of Turkey's Policy in Syria", Ankara, Turkey, Department of International Relations Middle East Technical University, p39.

5- Akturk Sener,( 2017), “Turkey's Role In The Arab Spring And The Syrian Conflict”, Turkish Policy Quarterly, Volume 15 Number 4, Winter, p88.

6- Guzansky Yoel,( 2015), "The Arab Gulf States and Reform in the Middle East: Between Iran and Arab Spring”, London, UK, Palgrave Macmillan, p40.

7- Goodrazi Jubin, "Iran and Syria: The Iran Primer", United States Institute of Peace, retrieved from:

https://iranprimer.usip.org/resource/iran-and-syria

8- Frederic M. Wehrey, (2014), "Sectarian Politics in the Gulf: From Iraq War to the Arab uprisings", New York, USA, Columbia University Press, p44.

9- Guzansky Yoel, (2015), "The Arab Gulf States and Reform in the Middle East: Between Iran and Arab Spring", London, UK, Palgrave Macmillan, p39.

10- Ma'oz Moshe, (2007), “The Shii Crescent: Myth and Reality", the Saban Center in Brookings Institution, analysis paper, , Number15, November, p07.

11- Walker Martin,(2006), "The Revenge of the Shia", Wilson Quarterly, autumn.

12- Kristian Ulrichsen, (2009), “Gulf Security: Changing internal and external dynamics", The Center for The Study of Global Governance, May, pp11-12.

13- Hydemann Steven, (2013), “Syria's Uprising: Sectarianism, regionalization, and State order in the Levant", working paper, $\mathrm{N}^{\circ} 119$, May, p10.

14- Catar Sabina, (2015),"Kurdish Political Parties in Syria" in Wolfgang Taucher and others "The Kurds: History, Religion, Language, Politics", Austria, Austrian Federal Ministry of the Interior, p112.

15- Schmidinger Thomas, (2018), "Rojava Revolution, War and the Future of Syria's Kurds", London, UK, Pluto Press, p79.

16- Harriet Allsopp,(2015), "The Kurds of Syria: Political Parties and Identity in the Middle East", London, I.B.Tauris and Co Ltd, p15.

17- Gunes Cengiz and Robert Lowe, (2015), “The Impact of the Syrian War on Kurdish Politics across the Middle East", London, UK, Research Paper, Middle East and North Africa Programme, the Royal Institute of International Affairs, Chatham House, , July, p04.

18- Gunes Cengiz, (2019), "The Kurds in New Middle East: The Changing Geopolitics of a Regional Conflict", London, UK, Palgrave Macmillan, p61

19- Bengio Ofra,(2014), "The Islamic State: A Catalyst for Kurdish nationbuilding", TelAviv Notes, Vol 08, $\mathrm{N}^{\circ} 18,07^{\text {th }}$ October ,The Moshe Dayan Center for Middle Eastern and African Studies p04.

20- Bengio Ofra, Ibid, pp03-04.

21- William Harris, (2018), "Quicksilver War: Syria, Iraq and the Spiral of Conflict", New York, US, Oxford University Press, p105.

22- Osoegawa Taku, (2013), "Syria and Lebanon: International relations and Diplomacy in the Middle East", London, UK, I.B.Tauris, p91. 
23- Osoegawa Taku Osoegawa, op cit.

24- International Crisis Group, (2012), “A Precarious Balancing Act: Lebanon and the Syrian conflict”, Middle East report $\mathrm{N}^{\circ} 132$, p01.

25- International Crisis Group,(2014), "Lebanon's Hezbollah turns Eastward to Syria", Middle East report, $\mathrm{N}^{\circ} 153$, May $14^{\text {th }}, \mathrm{p} 18$.

26- Philips Christopher, (2015), "Sectarianism and conflict in Syria", Third world quarterly, London, UK, Queen Mary, university of London, Vol.36, $\mathrm{N}^{\circ} 2,357-376$, Routledge, $14^{\text {th }}$ May, p 359.

27- Ibid.

28- International Crisis Group, “A Precarious Balancing Act: Lebanon and the Syrian conflict", op.cit

29- Bahout Joseph, (2014), "Lebanon at the Brink: The Impact of the Syrian Civil War", , Brandies University, No 76, Crown Center for Middle East Studies, p03.

30- Geneive Abdo,(2017), "The New Sectarianism: The Arab uprisings and the rebirth of the Shia-Sunni Divide", , New York, USA,Oxford University Press,p79.

31- Aaron Reese, (2013), "Sectarian and Regional Conflict in the Middle east", Middle East security report 13, p10.

32- Genieve Abdo, op cit, p22.

33- Guidero Amanda and Hallward Maia Carter, (2019),"Global responses to Conflict and Crisis in Syria and Yemen", Switzerland, Palgrave Macmillan, p21. 